\title{
Attribution of atmospheric sulfur dioxide over the English Channel to dimethyl sulfide and changing ship emissions
}

\author{
Mingxi Yang, Thomas G. Bell, Frances E. Hopkins, and Timothy J. Smyth \\ Plymouth Marine Laboratory, Prospect Place, Plymouth, PL1 3DH, UK \\ Correspondence to: Mingxi Yang (miya@pml.ac.uk) and Thomas G. Bell (tbe@pml.ac.uk)
}

Received: 19 January 2016 - Published in Atmos. Chem. Phys. Discuss.: 25 January 2016

Revised: 8 April 2016 - Accepted: 11 April 2016 - Published: 18 April 2016

\begin{abstract}
Atmospheric sulfur dioxide $\left(\mathrm{SO}_{2}\right)$ was measured continuously from the Penlee Point Atmospheric Observatory (PPAO) near Plymouth, United Kingdom, between May 2014 and November 2015. This coastal site is exposed to marine air across a wide wind sector. The predominant southwesterly winds carry relatively clean background Atlantic air. In contrast, air from the southeast is heavily influenced by exhaust plumes from ships in the English Channel as well as near Plymouth Sound. A new International Maritime Organization (IMO) regulation came into force in January 2015 to reduce the maximum allowed sulfur content in ships' fuel 10-fold in sulfur emission control areas such as the English Channel. Our observations suggest a 3 -fold reduction in shipemitted $\mathrm{SO}_{2}$ from 2014 to 2015. Apparent fuel sulfur content calculated from coincidental $\mathrm{SO}_{2}$ and carbon dioxide $\left(\mathrm{CO}_{2}\right)$ peaks from local ship plumes show a high level of compliance to the IMO regulation (> $95 \%)$ in both years $(\sim 70 \%$ of ships in 2014 were already emitting at levels below the 2015 cap). Dimethyl sulfide (DMS) is an important source of atmospheric $\mathrm{SO}_{2}$ even in this semi-polluted region. The relative contribution of DMS oxidation to the $\mathrm{SO}_{2}$ burden over the English Channel increased from about one-third in 2014 to about one-half in 2015 due to the reduction in ship sulfur emissions. Our diel analysis suggests that $\mathrm{SO}_{2}$ is removed from the marine atmospheric boundary layer in about half a day, with dry deposition to the ocean accounting for a quarter of the total loss.
\end{abstract}

\section{Introduction}

The trace gas sulfur dioxide $\left(\mathrm{SO}_{2}\right)$ is important for atmospheric chemistry (Charlson and Rodhe, 1982) as a principal air pollutant (e.g., contributor to acid rain). Atmospheric oxidation of $\mathrm{SO}_{2}$ leads to sulfate aerosols, which influence the Earth's radiative balance directly by scattering incoming radiation and indirectly by affecting cloud formation (Charlson et al., 1987). Important natural sources of $\mathrm{SO}_{2}$ include the atmospheric oxidation of dimethyl sulfide (DMS, which is formed by marine biota) and volcanic eruptions. Anthropogenic fossil fuel combustion also produces $\mathrm{SO}_{2} . \mathrm{SO}_{2}$ is removed from the lower atmosphere by dry deposition and oxidation in both the gas phase and the aqueous phase. The relatively slow gas phase oxidation of $\mathrm{SO}_{2}$ leads to sulfuric acid vapor, which usually condenses upon pre-existing aerosols but can nucleate to form new particles under specific conditions (e.g., Clarke et al., 1998). The much faster aqueous phase oxidation of $\mathrm{SO}_{2}$ takes place primarily in cloud water (e.g., Hegg, 1985; Yang et al., 2011b) and leads to particulate sulfate, which is removed from the atmosphere mainly by wet deposition.

$\mathrm{SO}_{2}$ production from DMS occurs principally via daytime oxidation by the hydroxyl radical $(\mathrm{OH})$. From observations in the equatorial Pacific, Bandy et al. (1996) and Chen et al. (2000) reported a clear increase in $\mathrm{SO}_{2}$ mixing ratio and coincidental decrease in DMS during the day. This anticorrelation confirmed that DMS oxidation by $\mathrm{OH}$ is an important source of $\mathrm{SO}_{2}$ over the remote ocean. Yang et al. (2011b) showed that DMS remains the predominant sulfur precursor in the marine atmospheric boundary layer of the relatively unpolluted southeast Pacific.

In the last few decades, $\mathrm{SO}_{2}$ emissions from terrestrial combustion sources such as power plants and ground trans- 
portation have been subject to strict regulation (e.g., UK Clean Air Acts). These forms of legislation have significantly reduced the atmospheric sulfur burden over land in North America and Europe (e.g., Lynch et al., 2000; Malm et al., 2002; Vestreng et al., 2007). Unlike terrestrial $\mathrm{SO}_{2}$ emissions, ship emissions were for a long period excluded from international environmental agreements. This allowed ships to burn low-grade fuels with high sulfur content (i.e., heavy fuel oils), which resulted in large $\mathrm{SO}_{2}$ emissions from ship engine exhausts (hereafter ship emissions). In addition to $\mathrm{SO}_{2}$, ship exhausts also contain carbon dioxide $\left(\mathrm{CO}_{2}\right)$, nitrogen oxides, carbon monoxide, heavy metals, organic toxins, and particulates such as black carbon (e.g., Agrawal et al., 2008). Closer to the coast and near shipping lanes, ship emissions can be an important contributor to the atmospheric sulfur budget (Capaldo et al., 1999; Dalsoren et al., 2009). Eyring et al. (2005a) estimated that global, transport-related emissions of $\mathrm{SO}_{2}$ from ships in the year 2000 were approximately 3-fold greater than from road traffic and aviation combined. Air-quality models predict that aerosols resulting from ship emissions contribute to tens of thousands of cases of premature mortality near coastlines (Corbett et al., 2007). Impacts may be further exacerbated as the global population expands and shipping-based trade increases (Eyring et al., 2005b).

In January 2015, new air-quality regulations from the International Maritime Organization (IMO), an agency of the United Nations, came into force. These regulations aim to reduce sulfur emissions in sulfur emission control areas (SECAs) by decreasing the maximum allowed sulfur content in ship fuel from $1 \%$ (regulation since 2010 ) to $0.1 \%$ by mass. The English Channel and the surrounding European coastal waters are within a SECA. The IMO further intends to reduce the ship's fuel sulfur content (FSC) in the open ocean from the current cap of 3.5 to $0.35 \%$ by 2020 . As an alternative to burning lower sulfur fuel, these regulations also allow ships to use scrubber technology to reduce $\mathrm{SO}_{2}$ emissions. Winebrake et al. (2009) estimated that such reduced emissions would approximately halve the premature mortality rate in coastal regions. A decrease in anthropogenic sulfur emission is also expected to make DMS a relatively more important sulfur source in regions such as the North Atlantic.

There have been few direct measurements of ship emissions that are relevant for a regional scale. Kattner et al. (2015) reported large reductions of $\mathrm{SO}_{2}$ in ship plumes from 2014 to 2015 near the mouth of the Hamburg harbor on the river Elbe, which is about $100 \mathrm{~km}$ away from the North Sea. Using the $\mathrm{SO}_{2}: \mathrm{CO}_{2}$ ratio in ship plumes, they found a high compliance rate of $\sim 95 \%$ after the stricter regulation in January 2015. Based on $\mathrm{SO}_{2}$ and $\mathrm{CO}_{2}$ measurements from the Saint Petersburg Dam, which spans the Gulf of Finland and separates the Neva Bay from the rest of the Baltic Sea, Beecken et al. (2015) found a compliance rate of 90-97\% in 2011 and 2012. They observed a bimodal distribution in the ship's FSC, with the lower mode centering around $\sim 0.2 \%$ by mass and the higher mode centering around $\sim 0.9 \%$. Compliance checks are mainly limited to manual checking of fuel $\operatorname{logs}$ and fuel quality certificates when ships are in port.

Global and regional ship emission estimates have typically been scaled from inventories for individual vessels in combination with information about ship traffic (e.g., Endresen et al., 2003; Collins et al., 2008; Matthias et al., 2010; Whall et al., 2010; Aulinger et al., 2016; Jalkanen et al., 2016). Accurate assessment of the success of IMO regulations requires long-term continuous observations at strategic locations. Here we present 1.5 years of continuous atmospheric $\mathrm{SO}_{2}$ measurements from the Penlee Point Atmospheric Observatory (PPAO) in the English Channel, one of the busiest shipping lanes in the world. The PPAO measurements date back to seven months before recent IMO sulfur regulations came into force, providing a reference point for future changes in emissions. The unique location of PPAO (Fig. 1; http://www.westernchannelobservatory.org. uk/penlee/) allows us to partition the atmospheric $\mathrm{SO}_{2}$ budget to natural (mostly dimethyl sulfide) and anthropogenic (mostly ship emission) sources.

\section{Experiment}

The PPAO is located on the western side of the mouth of Plymouth Sound (Fig. 1). See Yang et al. (2016) for detailed site description. About $11 \mathrm{~m}$ above mean sea level and $\sim 30 \mathrm{~m}$ away from the high water mark, the site is exposed to air that has traveled over water across a wide wind sector (from northeast to southwest). Near-continuous measurements of $\mathrm{SO}_{2}, \mathrm{CO}_{2}$, ozone $\left(\mathrm{O}_{3}\right)$, methane $\left(\mathrm{CH}_{4}\right)$, as well as standard meteorological parameters have been made at the PPAO since May 2014.

$\mathrm{SO}_{2}$ mixing ratio was measured every $10 \mathrm{~s}$ by an enhanced trace level pulsed fluorescence $\mathrm{SO}_{2}$ analyzer (Thermo Scientific, model 43i). The instrument noise level is about 0.06 parts per billion (ppb) at a $1 \mathrm{~min}$ averaging interval and $0.025 \mathrm{ppb}$ at a $5 \mathrm{~min}$ averaging interval. $\mathrm{O}_{3}$ mixing ratio was measured every $10 \mathrm{~s}$ by a dual-beam, UV absorption ozone monitor (2B Technologies, Inc., model 205), which has a noise level of about $2.2 \mathrm{ppb}$ at a $1 \mathrm{~min}$ averaging interval and $1.0 \mathrm{ppb}$ at a $5 \mathrm{~min}$ averaging interval. The $\mathrm{SO}_{2}$ and $\mathrm{O}_{3}$ sensors shared the same air inlet, which consisted of a $\sim 4 \mathrm{~m}$ long $0.64 \mathrm{~cm}$ outer diameter PFA (perfluoroalkoxy) tubing that extended just outside the air vent of the building $(\sim 2 \mathrm{~m}$ above ground and $\sim 13 \mathrm{~m}$ above mean sea level). A $5 \mu \mathrm{m}$ diameter Teflon filter was installed upstream of the instruments to reduce particulates in sampled air. The $\mathrm{O}_{3}$ instrument sampled through an additional $5 \mu \mathrm{m}$ particle filter. These filters were replaced approximately every 2-4 weeks. Blank measurements of $\mathrm{SO}_{2}$ and $\mathrm{O}_{3}$ were made simultaneously by directing sample air through the existing particle filters, $\sim 8 \mathrm{~m}$ of $0.64 \mathrm{~cm}$ outer diameter copper tubing (which efficiently 

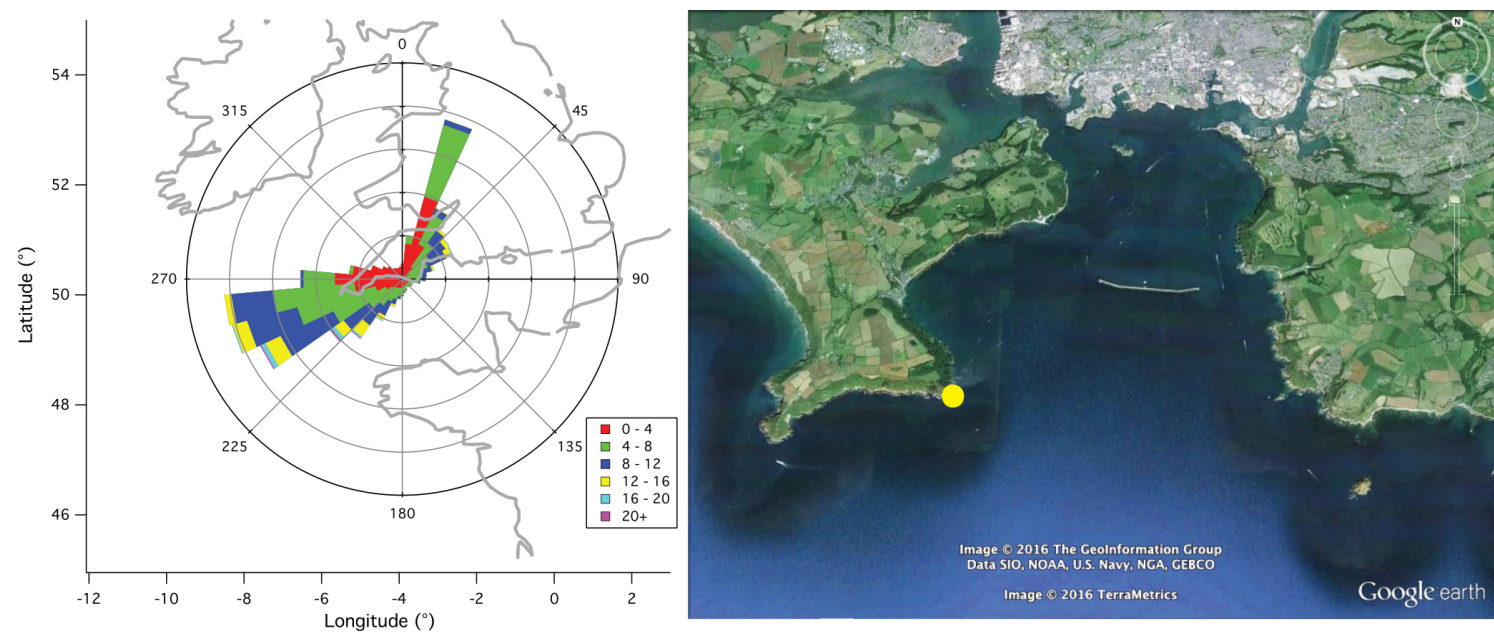

Figure 1. Wind rose at Penlee Point Atmospheric Observatory from 2014 to 2015 overlaid on a map of the British Isles (left), and a map showing the observatory (yellow circle) on the western side of the $4 \mathrm{~km}$ wide Plymouth Sound (right). The English Channel lies between the UK and northern France. Colors on the spokes correspond to wind speeds in units of $\mathrm{m} \mathrm{s}^{-1}$ and concentric circles indicate frequency of occurrence in $2.5 \%$ intervals (outer circle $=12.5 \%$ ). Winds predominantly came from the west/southwest at speeds of $4-12 \mathrm{~m} \mathrm{~s}-1$.

removed $\mathrm{SO}_{2}$ ), and an $\mathrm{O}_{3}$ scrubber. Linearly interpolated blanks are subtracted from the raw data. We checked the calibration of the $\mathrm{SO}_{2}$ instrument twice a year with a $\mathrm{SO}_{2}$ gas standard diluted in nitrogen (100 ppb, BOC). The measured $\mathrm{SO}_{2}$ mixing ratio was within a few percent of the gas standard. An $\mathrm{O}_{3}$ calibration device was unavailable during the duration of these measurements. However, an intercomparison with a recently calibrated $2 \mathrm{~B} \mathrm{O}_{3}$ Monitor showed that the accuracy of the $\mathrm{O}_{3}$ measurement at PPAO was within $\pm 5 \%$.

$\mathrm{CO}_{2}$ mixing ratio was measured by a Picarro cavity ringdown analyzer (G2311-f) every $0.1 \mathrm{~s}$ (see Yang et al., 2016 for details). Ambient air was drawn from a mast on the rooftop of the observatory (nominally at $\sim 18 \mathrm{~m}$ above mean sea level) through a $\sim 18 \mathrm{~m}$ long $0.95 \mathrm{~cm}$ outer diameter PFA tubing at about $15-30 \mathrm{~L} \mathrm{~min}^{-1}$ by a dry vacuum pump. The Picarro analyzer subsampled from this main flow via a $\sim 2 \mathrm{~m}$ long $0.64 \mathrm{~cm}$ outer diameter Teflon PFA tubing and a high throughput dryer (Nafion PD-200T-24M) at a flow rate of $\sim 5 \mathrm{~L} \mathrm{~min}^{-1}$. The total delay time from the inlet tip to the analyzer was $1.9-3.3 \mathrm{~s}$. The instrument calibration was checked with a $\mathrm{CO}_{2}$ gas standard (BOC) and the accuracy was within $0.5 \%$. The instrument noise for $1 \mathrm{~min}$ averaged $\mathrm{CO}_{2}$ is less than $0.05 \mathrm{ppm}$.

$\mathrm{SO}_{2}, \mathrm{O}_{3}$, and meteorological parameters data were logged and time stamped by the same computer. Given the short inlet tubing length and the specified flow rates, the calculated delay time for these gases from the inlet tip to the sensors was less than $4 \mathrm{~s} . \mathrm{CO}_{2}$ data were logged on a separate computer (Picarro internal PC). Both computers were synchronized to network UTC clocks once a week. The time difference between the $\mathrm{SO}_{2} / \mathrm{O}_{3} /$ meteorology measurements and the $\mathrm{CO}_{2}$ measurements was less than $1 \mathrm{~min}$. We note that the gas inlets for both the $\mathrm{SO}_{2}$ and the $\mathrm{CO}_{2}$ instruments $(\sim 13$ and $18 \mathrm{~m}$ a.m.s.l.) were within the surface layer of the marine atmosphere; they should be sampling the same air mass (and the same ship plume) under typical meteorological conditions. Dispersion modeling from von Glasow et al. (2003) predicts that just $10 \mathrm{~s}$ after emission, a ship plume will have already expanded vertically to a height of $20 \mathrm{~m}$ from the surface.

\section{Results}

Figure 1 shows the frequency distribution of winds from 2014 to 2015 (wind distributions were nearly identical for these 2 years). Winds came predominantly from west/southwest at moderate to high speeds, which were typically associated with low-pressure systems in the North Atlantic and generally carried low mixing ratios of $\mathrm{SO}_{2}$ and $\mathrm{CO}_{2}$ (Yang et al., 2016). The wind sector between 110 and $250^{\circ}$ is unobstructed by land. The Rame Head peninsula sits $\sim 1.5 \mathrm{~km}$ west of PPAO, beyond which lie $\sim 40 \mathrm{~km}$ of coastal seas, the county of Cornwall (width of $\sim 30 \mathrm{~km}$ ), and the North Atlantic Ocean. The north/northeastern sector is more influenced by emissions from terrestrial anthropogenic sources, while winds from 50 to $110^{\circ}$ face the eastern side of Plymouth Sound, which is busy with ship traffic. The southeasterly sector is likely affected by emissions from local ships as well as distant pollution from the English Channel and continental Europe. According to the Devonport Naval Base Ship Movement Report, the total number of ships in Plymouth Sound varies from about 4000 per month in winter to 6000 per month in summer. The volume of ship traffic in the English Channel is about 15000 per month (Maritime and Coastguard Agency, 2007). 


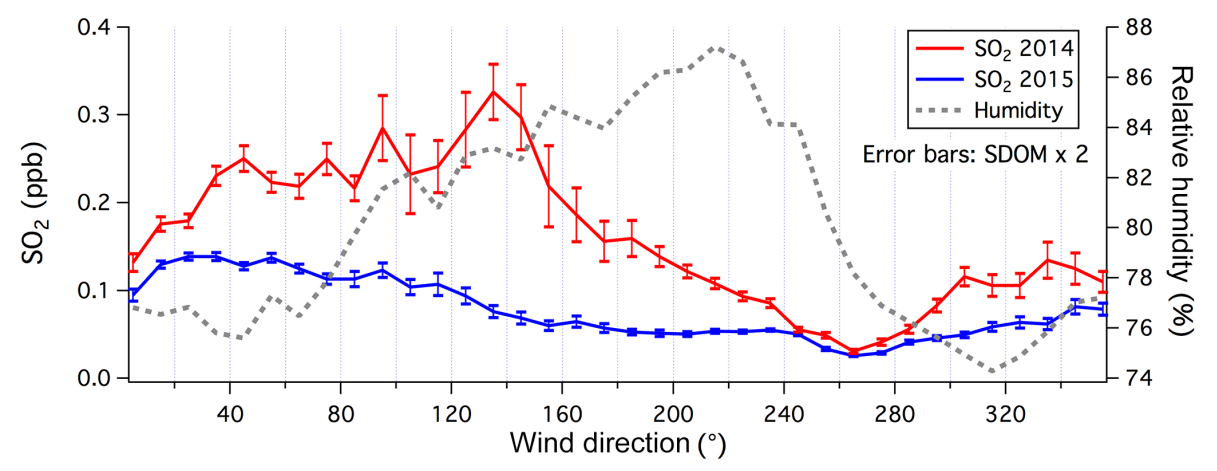

Figure 2. Averaged $\mathrm{SO}_{2}$ mixing ratio and relative humidity vs. wind direction for year 2014 and 2015 . Error bars on $\mathrm{SO}_{2}$ indicate 2 standard errors. Elevated humidity marks the marine-influenced wind sector to be between about 60 and $260^{\circ}$. Higher and more variable $\mathrm{SO}_{2}$ mixing ratios were observed from the southeast, particularly in 2014. Icelandic volcano plumes (e.g., Fig. A1) were excluded from averaging.

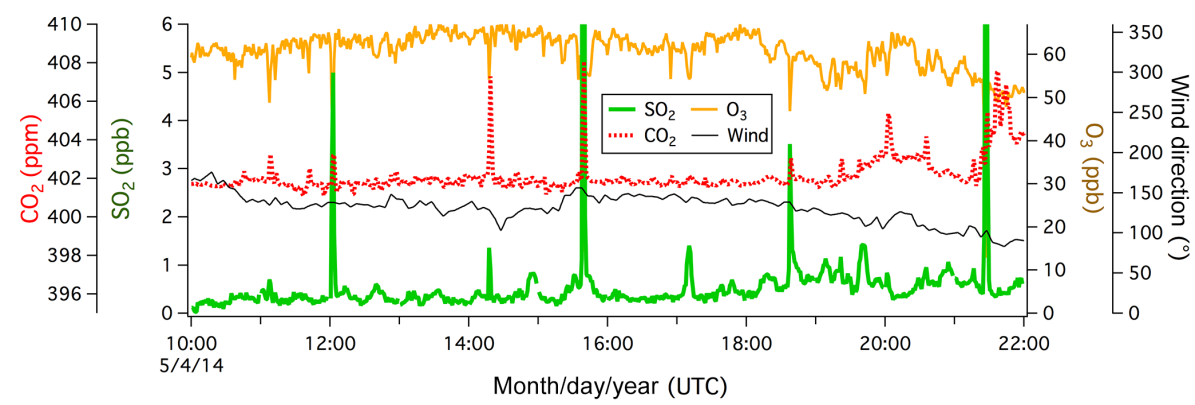

Figure 3. Example of local ship plumes on a day of southeasterly winds. Sharp peaks in $\mathrm{SO}_{2}$ and $\mathrm{CO}_{2}$ generally coincided with sudden depletions in $\mathrm{O}_{3}$ (1 min average).

Atmospheric $\mathrm{SO}_{2}$ and humidity varied significantly at PPAO depending on wind direction (Fig. 2). Increased relative humidity clearly indicates the marine-influenced wind sector from northeast to west/southwest. $\mathrm{SO}_{2}$ mixing ratios were higher and more variable when the air mass had traveled from the southeast than when it had come from the southwest. This elevated $\mathrm{SO}_{2}$ signal was more pronounced in 2014 (averaged between May and December) than in 2015 (averaged between January and November). The lowest $\mathrm{SO}_{2}$ mixing ratios were observed in the western wind sector in both years. In the appendix, we show episodes of large $\mathrm{SO}_{2}$ plumes from the Icelandic volcano Bárdarbunga as observed at PPAO. These volcanic events do not affect our analysis of $\mathrm{SO}_{2}$ in the marine atmosphere since winds were from the northwest.

\subsection{Ship plumes and $\mathrm{SO}_{2}$ frequency distributions}

Figure 3 shows a ship plume-influenced time series during a period of southeasterly winds. Sharp spikes in $\mathrm{SO}_{2}$ coincided with spikes in $\mathrm{CO}_{2}$ (e.g., at about 12:00 and 15:40 UTC), which lasted for just a few minutes and likely corresponded to local (within a few kilometers) ship emissions. $\mathrm{O}_{3}$ was significantly depleted in these plumes because of its reaction with nitrogen oxides $\left(\mathrm{NO}_{x}\right)$ emitted from ships. A lower, broader hump in $\mathrm{SO}_{2}$ can also be observed between about 18:30 and 20:00 UTC. This was likely due to more distant ship emissions that have been diluted and mixed in the atmosphere. A concurrent increase in $\mathrm{CO}_{2}$ was not obvious during these $1.5 \mathrm{~h}$. Given the high background mixing ratio of $\mathrm{CO}_{2}(\sim 400 \mathrm{ppm})$, ship plumes result in much smaller (additional) signal : background ratios for $\mathrm{CO}_{2}$ than for $\mathrm{SO}_{2}$. As a result, $\mathrm{CO}_{2}$ emitted from point sources tends to quickly become indistinguishable from the background with increasing distance (i.e., greater air dilution/dispersion). In Sect. 4.2, we use the ratio between the $\mathrm{SO}_{2}$ and $\mathrm{CO}_{2}$ peaks to estimate the ship's apparent FSC.

Figure 4 shows the histograms of $\mathrm{SO}_{2}$ mixing ratios (from 5 min averages) in 2014 and 2015. We have separated the data into two wind sectors, southeast $\left(80-170^{\circ}\right)$ and southwest $\left(210-250^{\circ}\right)$. The southeastern sector encompasses the English Channel while avoiding most of the UK landmass. The southwestern sector, with largely an unobstructed oceanic fetch of thousands of kilometers, bypasses the northwestern coast of France as well as the busiest part of the shipping lanes (see ship's Automatic Identification System maps from Jalkanen et al., 2016). On average, winds came from our SW sector 7.5 days a month and came from the SE sector 2.1 days a month. The $\mathrm{SO}_{2}$ distributions shifted towards lower mixing ratios in 2015 compared to 2014, especially 

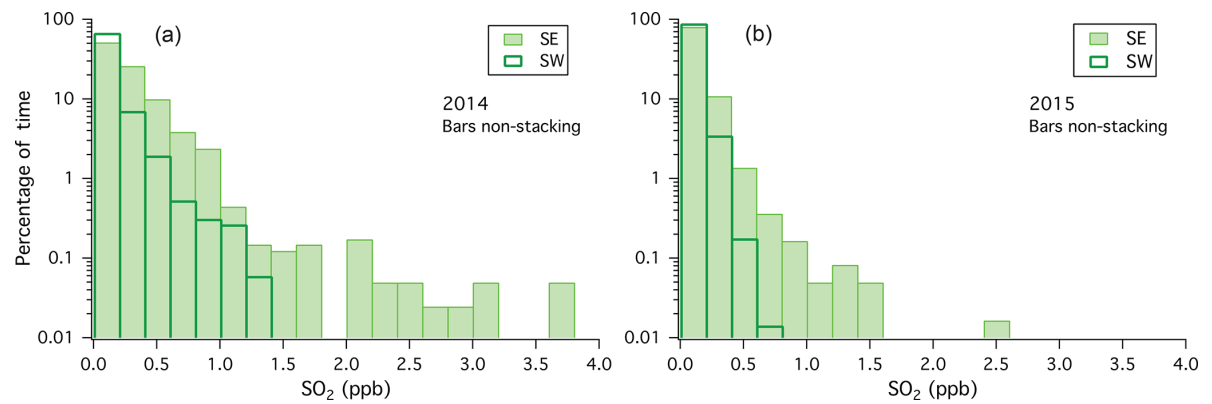

Figure 4. Histogram distributions of $\mathrm{SO}_{2}$ mixing ratios in 2014 (a) and 2015 (b) from the southeastern and southwestern wind sectors (5 min average). Distributions are normalized to the total number of observations from the respective wind sectors.
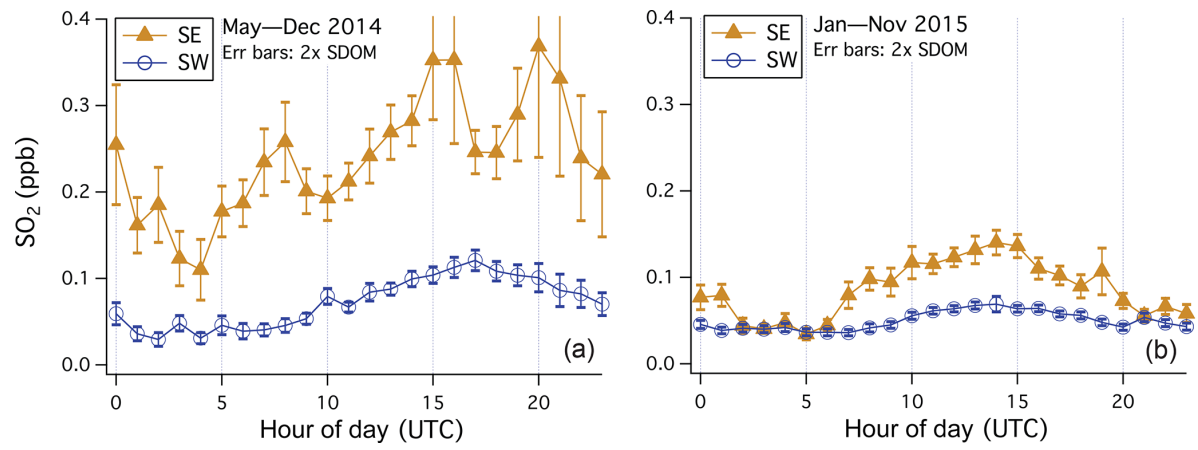

Figure 5. Average diel cycles of $\mathrm{SO}_{2}$ mixing ratio, separated into the southeastern and southwestern wind sectors for 2014 (a) and 2015 (b). $\mathrm{SO}_{2}$ in the southwestern sector showed diel variability that is largely consistent with DMS oxidation. $\mathrm{SO}_{2}$ in the southeastern sector was significantly lower and less variable in 2015 than in 2014.

for the southeastern wind sector. For example, $\mathrm{SO}_{2}$ mixing ratios from the southeast exceeded $0.5 \mathrm{ppb} \sim 1 \%$ of the time in 2015 (compared to $\sim 11 \%$ in 2014).

\subsection{Diel variability in $\mathrm{SO}_{2}$}

We compute the mean diel cycles of $\mathrm{SO}_{2}$ mixing ratio in the southeastern and the southwestern sectors for both 2014 (May to December) and 2015 (January to November), which are shown in Fig. 5. The long averaging periods help to reduce measurement noise and also allow variability caused by horizontal transport to largely cancel. $\mathrm{SO}_{2}$ from the southwest shows a very tight diel cycle and low variability (relative standard errors less than $10 \%$ ). $\mathrm{SO}_{2}$ mixing ratio was the lowest near sunrise, increased throughout the day, and decreased after sunset. This diel cycle suggests that $\mathrm{SO}_{2}$ from the southwest came primarily from the photooxidation of biologically derived DMS. Differences in the mean $\mathrm{SO}_{2}$ diel cycles in 2014 and 2015 for the southwestern sector are largely due to the different months used in the averaging. Considering only the months of May to November, mean $\mathrm{SO}_{2}$ mixing ratios in this wind sector for the 2 years differ by only $\sim 0.01 \mathrm{ppb}$ (see Sect. 4.1).

$\mathrm{SO}_{2}$ from the southeast was about 3 times higher and also more variable than from the southwest in 2014. Peaks in $\mathrm{SO}_{2}$ were observed in the morning, mid-afternoon, and early evening. These timings are consistent with the schedule of channel-crossing ferries, which enter Plymouth Sound at least once a day from approximately due south. In $2015, \mathrm{SO}_{2}$ from the southeast was about 2 times higher than from the southwest and variability in $\mathrm{SO}_{2}$ mixing ratio was reduced. In both years, $\mathrm{SO}_{2}$ from the southeast shows an underlying diel trend (i.e., increasing during the day and decreasing at night) that suggests contributions from DMS oxidation. This implies that $\mathrm{SO}_{2}$ from the southeast is made up of at least two major components: ship emissions and DMS oxidation.

\section{3 $\mathrm{SO}_{2}$ from DMS oxidation}

The $\mathrm{SO}_{2}$ diel cycle from the southwestern wind sector (Fig. 5) is consistent with daytime $\mathrm{SO}_{2}$ production from DMS oxidation by the $\mathrm{OH}$ radical (e.g., Bandy et al., 1996; Yang et al., 2009). DMS was measured using a highresolution proton-transfer-reaction mass spectrometer (Ionicon, Austria) from the rooftop of the PML building in Plymouth ( $\sim 6 \mathrm{~km}$ north/northeast of PPAO) in 2012 (Yang et al., 2013) and in 2015. Recently calibrated transmission efficiencies from the manufacturer and kinetic reaction rates from Zhao and Zhang (2004) were used to derive the DMS mixing ratio (uncertainty $\leq 40 \%$ ). DMS levels in marine air 
from the southwest and southeast were comparable during the 2015 measurement period (21 April to 15 May). The mean DMS diel cycle from the marine sector (Fig. 6) clearly shows an anticorrelation with shortwave irradiance, implying daytime oxidation by $\mathrm{OH}$ (mostly to $\mathrm{SO}_{2}$ ). The diel amplitude in DMS mixing ratio was $\sim 0.09 \mathrm{ppb}$. A day/night difference in atmospheric DMS was also observed from the PML rooftop in June 2012 from marine air (Yang et al., 2013).

The conversion efficiency from DMS to $\mathrm{SO}_{2}$ due to $\mathrm{OH}$ oxidation is about 70-90\% (Davis et al., 1999; Chen et al., 2000; Shon et al., 2001). At a conversion efficiency of $80 \%$, $0.09 \mathrm{ppb}$ of oxidized DMS would lead to about $0.07 \mathrm{ppb}$ of $\mathrm{SO}_{2}$ produced during the day. In comparison, over the 1.5 years of observations at PPAO the mean amplitude of the $\mathrm{SO}_{2}$ diel cycle from the southwest was $\sim 0.06 \mathrm{ppb}$. This comparison is qualitative because DMS was only measured during the spring/summer periods and at a different location. Nevertheless, it appears that within the measurement uncertainties DMS oxidation can account for the vast majority of the observed $\mathrm{SO}_{2}$ diel cycle from the southwestern wind sector.

\subsection{Removal of $\mathrm{SO}_{2}$ from the marine atmosphere}

$\mathrm{SO}_{2}$ is mainly removed from the marine boundary layer via aqueous oxidation (e.g., cloud processing), deposition to the ocean, and possibly dilution by the free tropospheric air. We can approximate the total loss of $\mathrm{SO}_{2}$ from the nighttime change in the averaged $\mathrm{SO}_{2}$ mixing ratio (daytime $\mathrm{SO}_{2}$ oxidation is very slow). This calculation assumes no temporal trend in any nocturnal ship emissions (on a diel timescale) and a constant marine boundary layer height. In a polluted marine environment, a small amount of $\mathrm{SO}_{2}$ could be formed at night via DMS oxidation by the nitrate radical $\left(\mathrm{NO}_{3}\right.$; Yvon et al., 1996), a process we neglect here. A linear fit to the nighttime decrease of $\mathrm{SO}_{2}$ from the southwest in 2014 (Fig. 5a) yields a total loss rate of about $0.2 \mathrm{ppb}$ per day. The average $\mathrm{SO}_{2}$ mixing ratio was about $0.1 \mathrm{ppb}$ in the evening hours, which implies a $\mathrm{SO}_{2}$ residence time of approximately $0.5 \mathrm{~d}$. In 2015 , the total loss rate was about 0.1 ppb per day, which also implies a $\mathrm{SO}_{2}$ residence time of $\sim 0.5 \mathrm{~d}$. This residence time is in close agreement with previous estimates in the marine atmosphere (e.g., Cuong et al., 1975; Yang et al., 2011b).

We compute the dry deposition flux of $\mathrm{SO}_{2}$ to the surface ocean as $-V_{\mathrm{d}} \cdot\left[\mathrm{SO}_{2}\right]$, where $\left[\mathrm{SO}_{2}\right]$ is the atmospheric $\mathrm{SO}_{2}$ concentration and $V_{\mathrm{d}}$ is the deposition velocity of $\mathrm{SO}_{2}$. Upon contact with seawater, $\mathrm{SO}_{2}$ rapidly dissociates to form $\mathrm{HSO}_{3}^{-}$ and then sulfite (Eigen et al., 1964). The effective solubility of $\mathrm{SO}_{2}$ in seawater $(\mathrm{pH} \sim 8)$ due to this chemical enhancement is very large (dimensionless water:air solubility of about $5 e^{8}$ ), which means that air-sea $\mathrm{SO}_{2}$ exchange should be gas phase controlled. Oxidation to sulfate permanently removes sulfite from the surface ocean with a timescale of minutes to hours (Schwartz, 1992). The combination of a low aqueous $S(\mathrm{IV})$ concentration (e.g., Campanella et al., 1995;

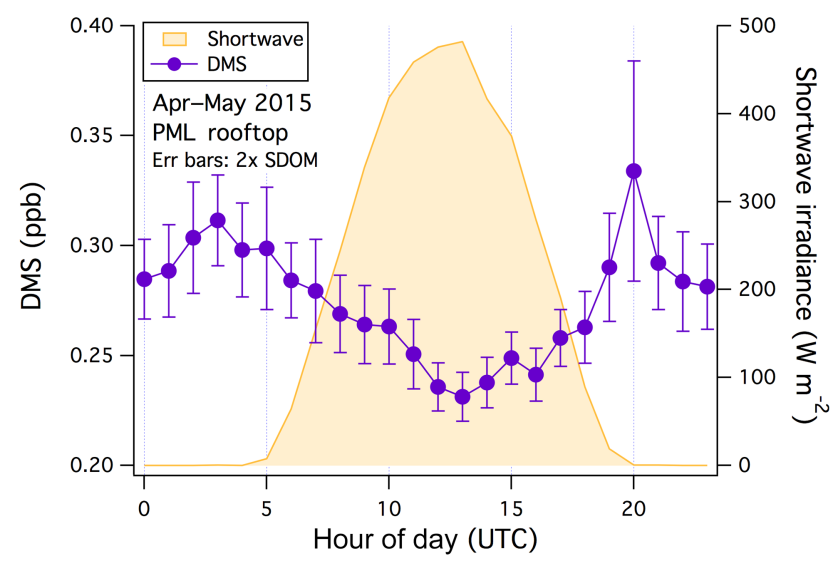

Figure 6. Average diel variability in DMS mixing ratio and shortwave irradiance, measured from the PML rooftop between April and May 2015 (wind from the marine sector). Error bars indicate 2 standard errors.

Hayes et al., 2006) and a high effective solubility results in a near-zero interfacial $\mathrm{SO}_{2}$ concentration that is in equilibrium with seawater (e.g., Liss and Slater, 1974). We compute the deposition velocity of $\mathrm{SO}_{2}$ using the COARE gas transfer model (Fairall et al., 2011), which utilizes the airside diffusivity of $\mathrm{SO}_{2}$ from Johnson (2010) and the measured wind speed at PPAO. Diel cycles in $\mathrm{SO}_{2}$ deposition flux (Fig. 7) resemble the mirror image of $\mathrm{SO}_{2}$ mixing ratio. For the southwestern wind sector, the average $\mathrm{SO}_{2}$ deposition flux was about -1 to $-2 \mu$ mole $\mathrm{m}^{-2} \mathrm{~d}^{-1}$.

For the southeastern sector, deposition flux averaged about $-3 \mu$ mole $\mathrm{m}^{-2} \mathrm{~d}^{-1}$ in 2014 and $-1 \mu$ mole $\mathrm{m}^{-2} \mathrm{~d}^{-1}$ in 2015. Interestingly, while $\mathrm{SO}_{2}$ mixing ratio from the southeast was still higher than from the southwest in 2015, deposition fluxes between the two wind sectors were comparable. This is because wind speeds were typically lower from the southeast. Overall, dry deposition removes $\mathrm{SO}_{2}$ from a wellmixed, $1 \mathrm{~km}$ deep marine atmospheric boundary layer with a timescale of $\sim 2$ days at PPAO. It accounted for approximately a quarter of the total $\mathrm{SO}_{2}$ losses, similar to previous findings (e.g., Yang et al., 2011b).

\section{Discussion}

\subsection{Long-term changes in $\mathrm{SO}_{2}$ and ship emissions}

We evaluate the long-term trends in $\mathrm{SO}_{2}$ from different wind sectors in order to understand seasonal variability and assess any changes due to ship emissions. $\mathrm{SO}_{2}$ mixing ratios from the southeast and the southwest are averaged into monthly intervals (Fig. 8). Mean $\mathrm{SO}_{2}$ from the southwest in the summer months were comparable between 2014 and 2015. In contrast, $\mathrm{SO}_{2}$ from the southeast was significantly lower in summer 2015 than in summer 2014. For both wind sectors, lower $\mathrm{SO}_{2}$ mixing ratios were observed in winter/early 

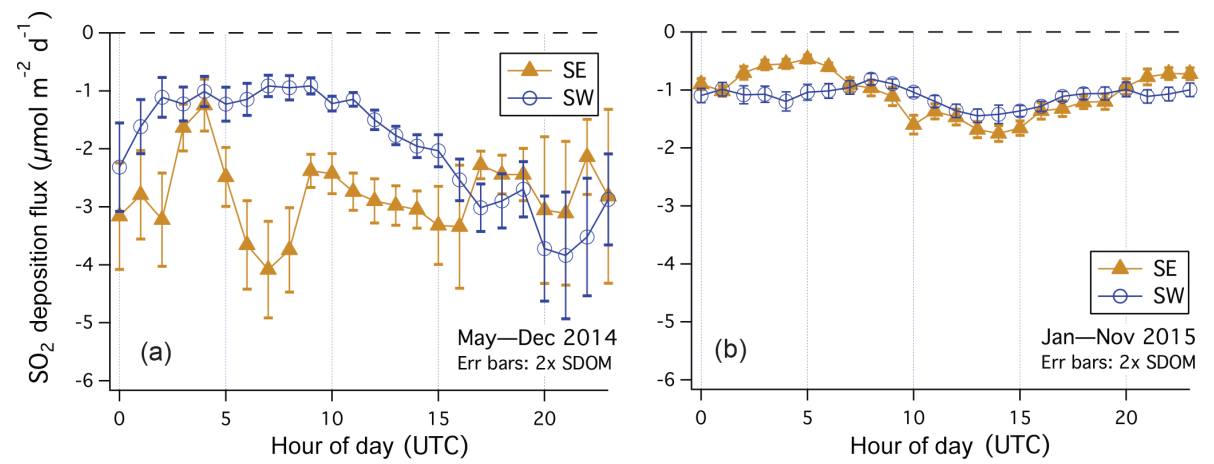

Figure 7. Mean diel cycles in the wind speed-dependent $\mathrm{SO}_{2}$ deposition flux, separated into the southeastern and southwestern wind sectors for year 2014 (a) and 2015 (b). Error bars indicate 2 standard errors. $\mathrm{SO}_{2}$ deposition flux was significantly greater in the southeastern sector than in the southwestern sector in 2014.

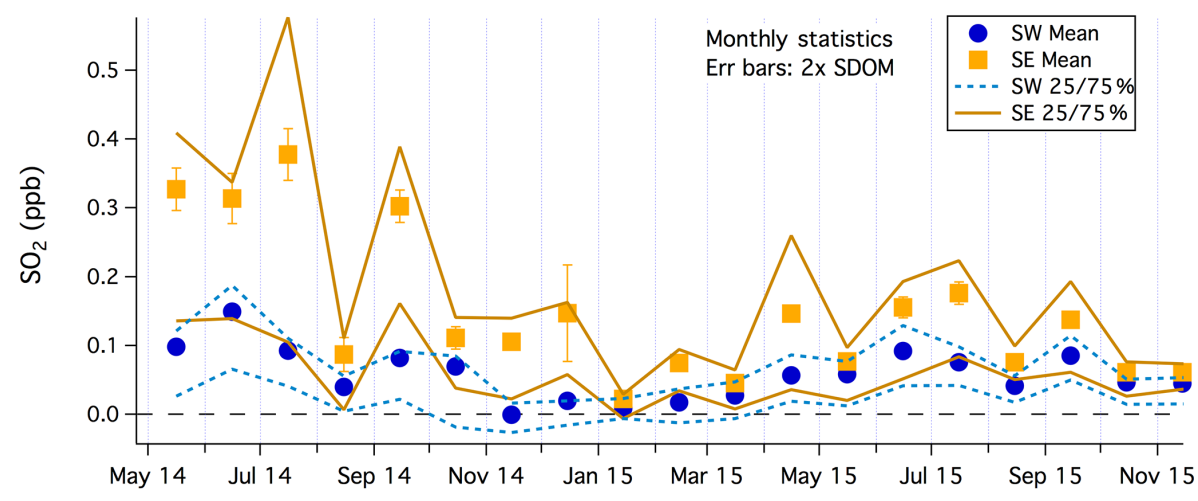

Figure 8. Monthly means and 25th/75th percentiles of $\mathrm{SO}_{2}$ mixing ratio from southeastern and southwestern wind sectors. $\mathrm{SO}_{2}$ from the southwest shows a clear seasonal cycle, with higher values in summer/early autumn and lower values in winter/early spring. A similar underlying seasonal variability is also apparent in $\mathrm{SO}_{2}$ from the southeastern sector.

spring compared to summer/early autumn. The seasonal cycle in $\mathrm{SO}_{2}$ from the southwest is consistent with the variability in surface seawater DMS concentration previously measured at the nearby L4 mooring station $(\sim 6 \mathrm{nM}$ in summer and $\sim 1 \mathrm{nM}$ in winter; Archer et al., 2009). Using those seawater DMS concentrations, local wind speeds and temperatures, and the DMS air-sea transfer velocity from Yang et al. (2011a), we predict DMS fluxes on the order of $\sim 10$ and $3 \mu$ mole $\mathrm{m}^{-2} \mathrm{~d}^{-1}$ for the summer and winter, respectively. These fluxes would be sufficient to account for the observed $\mathrm{SO}_{2}$ burden from the southwest $(\sim 0.10 \mathrm{ppb}$ in summer and $\sim 0.02 \mathrm{ppb}$ in winter) assuming a $\mathrm{SO}_{2}$ residence time of 0.5 day in a $1 \mathrm{~km}$ deep marine boundary layer $(\sim 8$ and $\sim 2 \mu$ mole $\mathrm{m}^{-2} \mathrm{~d}^{-1}$ of sulfur required). In addition to lower seawater DMS concentrations in winter, less incoming irradiance and shorter daylight hours in those months will also reduce the photochemical production of $\mathrm{SO}_{2}$ from atmospheric DMS. Overall, we see that the seasonal cycle of $\mathrm{SO}_{2}$ in air from the southwest can largely be explained by natural variability.

The difference in $\mathrm{SO}_{2}$ mixing ratio between the southeastern and southwestern sectors $\left(\Delta \mathrm{SO}_{2}\right)$ is shown in Fig. 9 .
There is a fair amount of scatter in $\Delta \mathrm{SO}_{2}$, which is partly because $\mathrm{SO}_{2}$ measurements from the two wind sectors were not concurrent (i.e., winds could not be blowing from the southeast and southwest at any single moment). Nevertheless, mean ( \pm standard error) $\Delta \mathrm{SO}_{2}$ decreased from $\sim 0.15$ $( \pm 0.03) \mathrm{ppb}$ in 2014 to $\sim 0.05( \pm 0.01) \mathrm{ppb}$ in 2015 , with a sharp drop off coincident with the 1 January 2015 mandate for ship sulfur emission reduction.

We attribute $\Delta \mathrm{SO}_{2}$ to ship sulfur emissions based on the following assumptions: (I) $\mathrm{SO}_{2}$ from the southwest is from DMS oxidation only; (II) $\mathrm{SO}_{2}$ from the southeast is affected by both DMS oxidation and ship emissions; (III) DMS oxidation contributes equally to the $\mathrm{SO}_{2}$ burden in both the southeastern and southwestern wind sectors. Data from the southwestern sector will almost certainly include some ship contributions but the tightly constrained diel cycle in $\mathrm{SO}_{2}$ suggests this influence is fairly small. Automatic Identification System maps (http://www.marinetraffic.com/) indicate lower ship density and greater distances between the shipping lanes and PPAO (i.e., lower $\mathrm{SO}_{2}$ emissions, increased plume dilution, and greater $\mathrm{SO}_{2}$ removal) in the southwestern sector than in the southeastern sector. This information 


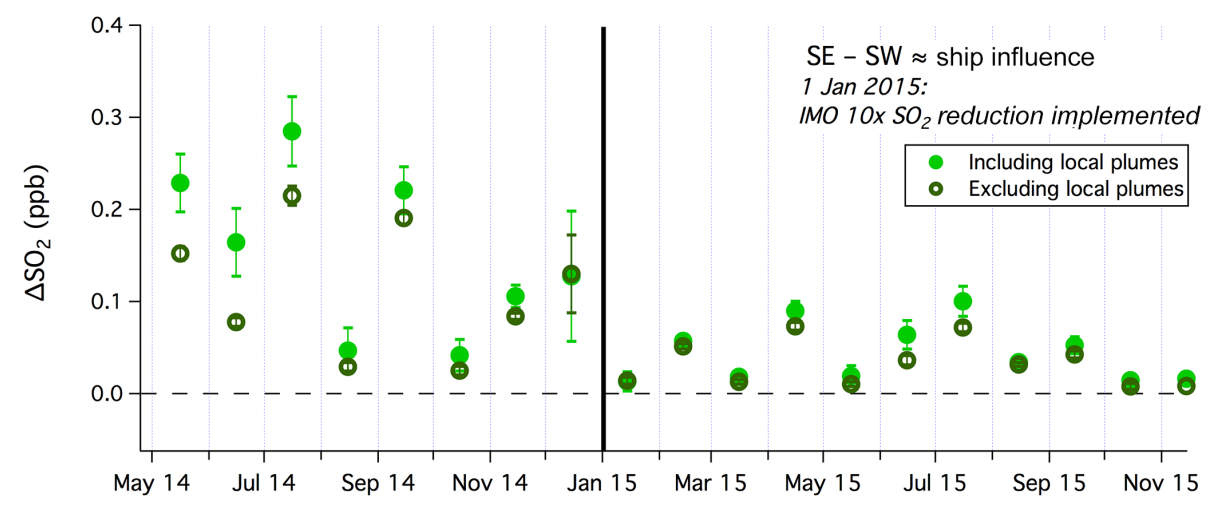

Figure 9. The difference between monthly averaged $\mathrm{SO}_{2}$ mixing ratios from the southeast and southwest $\left(\Delta \mathrm{SO}_{2}\right)$, which we consider to approximately represent ship emissions. $\Delta \mathrm{SO}_{2}$ including and excluding local ship plumes is shown. Error bars are propagated from 2 times the standard errors from each wind sector. Solid vertical line indicates the 1 January 2015 mandate for reduction in ship $\mathrm{SO}_{2}$ emissions.

corroborates the idea that ship emissions from the southwest only have a minor effect on our observations.

Entrainment from the free troposphere could bring anthropogenic $\mathrm{SO}_{2}$ into the marine boundary layer (e.g., Simpson et al., 2014), which is not accounted for here. We further assume negligible influence of terrestrial $\mathrm{SO}_{2}$ emissions (e.g., from continental Europe) in the southeastern sector because of atmospheric dilution and rapid removal of $\mathrm{SO}_{2}$ from the lower atmosphere (residence time $\sim 0.5 \mathrm{~d}$, see Sect. 3.4). The English Channel near Plymouth has a width of approximately $200 \mathrm{~km}$. At a speed of $5 \mathrm{~m} \mathrm{~s}^{-1}$, southeasterly winds blow over the channel in approximately half a day, comparable to the removal time.

\subsection{Local ship plumes and fuel sulfur content}

The $\mathrm{SO}_{2}$ signals from the southeast include local ship emissions (e.g., from ships entering/exiting Plymouth Sound) as well as more distant emissions from the English Channel. Local emissions usually appear as sharp spikes, while more distant emissions tend to have plumes that are broader and less intense due to atmospheric dilution. We use concurrent peaks in $\mathrm{SO}_{2}$ and $\mathrm{CO}_{2}$ to estimate the ships' apparent FSC. The FSC calculation assumes that all of the carbon and sulfur in fuel is released into the atmosphere during combustion. We use the word "apparent" here because our calculation reflects the downstream emissions rather than the actual fuel composition. Ships that "scrub" sulfur from stack emissions will have apparent FSC values that are lower than the actual FSC. To minimize the uncertainty in our estimate, we focus on well-resolved plumes from nearby ships only.

Simple dispersion modeling predicts that local ship plumes have a typical duration of a few minutes. For example, von Glasow et al. (2003) estimated the horizontal dispersion of a ship plume as

$H=H_{0} \cdot\left(t / t_{0}\right)^{0.75}$
$H_{0}$ and $H$ are the horizontal extents of a plume at the initial time $t_{0}(1 \mathrm{~s})$ and the time of interest $t$. The initial plume extent $\left(H_{0}\right)$ is assumed to be $10 \mathrm{~m}$. We estimate the horizontal dispersion of plumes emitted from an upwind distance of $2 \mathrm{~km}$ (e.g., halfway across Plymouth Sound) and $100 \mathrm{~km}$ (e.g., halfway across the English Channel). At a speed of $8 \mathrm{~m} \mathrm{~s}^{-1}$, wind travels 2 and $100 \mathrm{~km}$ in $\sim 4$ and $200 \mathrm{~min}$, respectively. Applying these timescales to Eq. (1) yields horizontal plume extents of 600 and $11000 \mathrm{~m}$. For a ship $2 \mathrm{~km}$ away that is traversing perpendicular to the mean wind at a speed of $4 \mathrm{~m} \mathrm{~s}^{-1}$, its emission should be observable at PPAO for $2.5 \mathrm{~min}$. A ship $100 \mathrm{~km}$ away would have a plume that is theoretically observable for nearly an hour. These timescales are roughly consistent with our time series observations (e.g., Fig. 3). Ships that do not travel perpendicular to the wind will have plumes that are observable for longer periods. Faster wind speeds or ship speeds shorten the duration of plume detection, and vice versa.

The following steps were used to separate local ship emissions from the background or more distant emissions based on 1 min average gas mixing ratios. All data processing was done with Igor Pro (WaveMetrics).

1. Apply $2 \mathrm{~h}$ running-median smoothing to the $\mathrm{SO}_{2}$ time series.

2. Identify "no plume" times as when the $1 \mathrm{~min}$ average $\mathrm{SO}_{2}$ was within $0.1 \mathrm{ppb}$ (i.e., < twice the instrument noise) of the smoothed $\mathrm{SO}_{2}$.

3. Subtract the linear interpolation of the "no plume" $\mathrm{SO}_{2}$ time series from the $1 \mathrm{~min}$ average $\mathrm{SO}_{2}$ time series to derive the $\mathrm{SO}_{2}$ deviations from the background $\left(\mathrm{SO}_{2}^{\prime}\right)$.

4. Apply the "FindPeak" function to $\mathrm{SO}_{2}^{\prime}$ to identify the time, height, leading edge, and trailing edge of a peak within non-overlapping $10 \mathrm{~min}$ windows. A minimum peak height of $0.2 \mathrm{ppb}$ (i.e., $>3$ times the instrument noise) was required for positive peak identification. 
5. Integrate $\mathrm{SO}_{2}^{\prime}$ between the leading edge and the trailing edge to yield the $\mathrm{SO}_{2}$ plume peak area.

The 10 min window in step 4 was chosen to minimize the occurrence of multiple plumes within a single window but also allow for identifications of plumes persisting for several minutes. A total of 816 distinct $\mathrm{SO}_{2}$ plumes were identified from May 2014 to November 2015 from the marine wind sector. The mean $\mathrm{SO}_{2}$ plume height (1 min average) was $1.35 \mathrm{ppb}$ in 2014 and $0.48 \mathrm{ppb}$ in 2015 , with a typical plume duration of $\sim 3 \mathrm{~min}$.

$\mathrm{CO}_{2}$ plumes from local ship emissions were identified in an analogous fashion based on an analysis of the 1 min average $\mathrm{CO}_{2}$ time series (i.e., independent of the $\mathrm{SO}_{2}$ analysis). The "no plume" $\mathrm{CO}_{2}$ threshold (step 2 above) was set to be $0.2 \mathrm{ppm}$, and the minimum peak height required for positive peak identification (step 4) was set to be $1.0 \mathrm{ppm}$. Based on these schemes, a total number of 1242 separate $\mathrm{CO}_{2}$ plumes were identified from May 2014 to November 2015, with a mean plume height of $2.6 \mathrm{ppm}$.

Apparent FSC is computed from coincidental $\mathrm{SO}_{2}$ and $\mathrm{CO}_{2}$ plume heights as well as plume areas $(N=245)$ following Kattner et al. (2015). To account for clock drift between the computers that recorded the $\mathrm{SO}_{2}$ and $\mathrm{CO}_{2}$ data, we allowed the times of the $\mathrm{SO}_{2}$ and $\mathrm{CO}_{2}$ peaks to differ by up to $1 \mathrm{~min}$. The results of these calculations for the marine wind sector are shown in Fig. 10. Gaps in observations were largely due to the $\mathrm{CO}_{2}$ analyzer malfunctioning or winds out of sector. The peak area and peak height methods yielded similar results. FSC from peak area appears to be slightly more variable, possibly due to a greater sensitivity toward the definition of plume baseline. Based on peak height, in 2014 the mean ( \pm standard error) FSC was $0.17( \pm 0.03) \%$, with $\sim 99 \%$ of the plumes below the IMO threshold of $1 \%$ FSC. About $70 \%$ of the plumes were already below $0.1 \%$ FSC in 2014. In 2015, mean FSC decreased to $0.047( \pm 0.003) \%$, with $\sim 99 \%$ of the plumes below the new IMO threshold of $0.1 \%$. FSC estimated from the peak area method shows slightly lower levels of compliance ( $\sim 95 \%$ for both years). The reduction in mean FSC from 2014 to 2015 is proportionally comparable to the decrease in $\Delta \mathrm{SO}_{2}$ computed in Sect. 4.1.

Our FSC estimates illustrate a fairly similar decreasing trend to that observed near the Hamburg harbor (Kattner et al., 2015). The mean FSC value at PPAO is approximately half of what was estimated by Kattner et al. (2015) for the year 2014 and is comparable to their estimate for 2015. However, our observations are different in several aspects. The vast majority of the ships entering/leaving Plymouth Sound are naval, commercial ferries, and private vessels according to the Devonport Naval Base Ship Movement Report. The number of large container ships entering Plymouth Sound is proportionally much lower than near Hamburg. Because the distances between ships and PPAO were not fixed (as opposed to spatially restricted sampling locations in Kattner et al., 2015, and Beecken et al., 2015), plumes observed at our site were usually more dilute and variable in duration. This variability made plume identification more challenging. We expect the bulk of the uncertainty in FSC to be due to instrument noise in $\mathrm{SO}_{2}$, which should be within $20 \%$ for plumes in 2015 and better in 2014. Total uncertainty in FSC may be higher though due to inexact plume baseline quantification, uncertainty in the threshold required for $\mathrm{SO}_{2}$ spike detection, and the small but variable time lag between the $\mathrm{SO}_{2}$ and $\mathrm{CO}_{2}$ measurements. A higher $\mathrm{SO}_{2}$ spike threshold could bias our FSC estimates towards plumes with greater sulfur content, while a lower threshold would be too close to the noise level of the measurement. Long-term records of another tracer (e.g., nitrogen oxides or black carbon) would allow for a more independent identification of ship plumes for the calculation of FSC. Finally, we reiterate that our FSC estimates are for well-resolved peaks from local ship plumes, which do not necessarily reflect ship emissions from the main shipping lanes of the English Channel.

\subsection{Top-down estimates of $\mathrm{SO}_{2}$ emissions from the English Channel}

We use $\Delta \mathrm{SO}_{2}$ with local ship emissions excluded (Fig. 9) to estimate distant anthropogenic $\mathrm{SO}_{2}$ emissions (e.g., from the English Channel). Without local spikes (i.e., the "no plume" $\mathrm{SO}_{2}$ time series in Sect. 4.2), the computed mean $\mathrm{SO}_{2}$ mixing ratio from the southwest is only slightly lower, as might be expected due to the relatively low ship density in that direction; in contrast, mean $\mathrm{SO}_{2}$ mixing ratio from the southeast is lowered by $\sim 0.04 \mathrm{ppb}$ in 2014 and $\sim 0.01 \mathrm{ppb}$ in 2015 . Approximately a quarter of the $\mathrm{SO}_{2}$ attributed to ship emissions in Sect. $4.1\left(\Delta \mathrm{SO}_{2}\right)$ was due to local ship plumes. $\Delta \mathrm{SO}_{2}$ excluding local ship emissions was $\sim 0.11( \pm 0.03)$ ppb in 2014 and $\sim 0.04( \pm 0.01) \mathrm{ppb}$ in 2015 . The largest differences in $\Delta \mathrm{SO}_{2}$ with and without nearby plumes occurred in the summer for both years, when the ship traffic was the heaviest.

We make an order of magnitude estimate for the ship emissions in the English Channel required to sustain the observed $\mathrm{SO}_{2}$ mixing ratios. This calculation assumes a $\mathrm{SO}_{2}$ residence time of $0.5 \mathrm{~d}$ in a well-mixed, $1 \mathrm{~km}$ deep marine atmospheric boundary layer. For this scenario it would take $\sim 9 \mu$ mole $\mathrm{m}^{-2} \mathrm{~d}^{-1}$ of $\mathrm{SO}_{2}$ from ships to account for a $\Delta \mathrm{SO}_{2}$ of $0.11 \mathrm{ppb}$ and $\sim 3 \mu$ mole $\mathrm{m}^{-2} \mathrm{~d}^{-1}$ of $\mathrm{SO}_{2}$ emission from ships to account for a $\Delta \mathrm{SO}_{2}$ of $0.04 \mathrm{ppb}$. Simplistic extrapolation of these fluxes to the area of the English Channel (about $75000 \mathrm{~km}^{2}$ ) yields a total ship $\mathrm{SO}_{2}$ emission of $\sim 16 \mathrm{Gg}$ per year in 2014 and $\sim 5 \mathrm{Gg}$ per year in 2015 . Compared to previous inventory-based $\mathrm{SO}_{2}$ emission estimates for the English Channel, our 2014 value is about $40 \%$ of that reported by Jalkanen et al. (2016) for 2011 and about a quarter of the Ship Emissions Inventory found in the UK Department for Environment Food and Rural Affairs (DEFRA) report (Whall et al., 2010). 


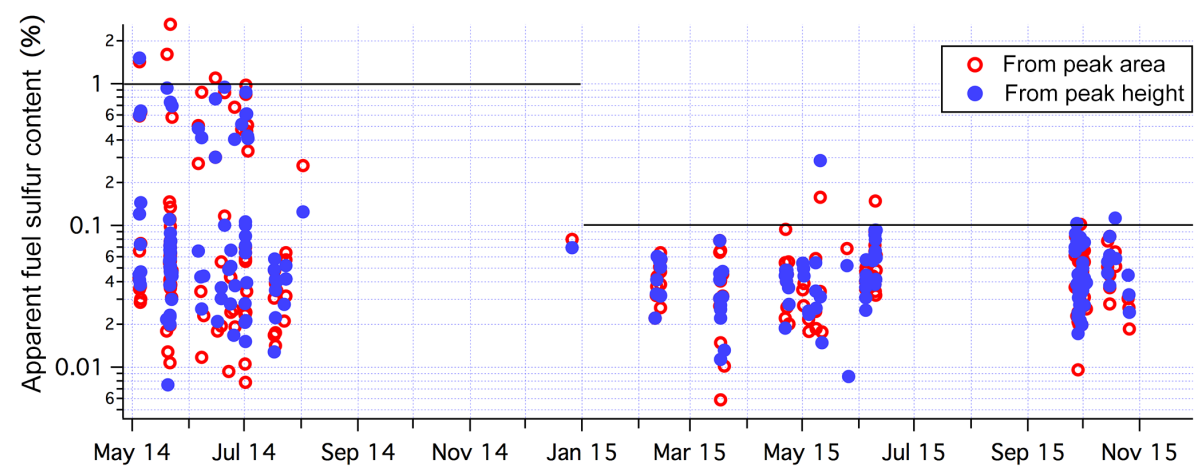

Figure 10. Apparent fuel sulfur content (FSC) estimated from peak areas as well as peak heights of coincidental $\mathrm{SO}_{2}$ and $\mathrm{CO}_{2}$ plumes $(1$ min averaged data). Solid horizontal lines indicate IMO fuel sulfur emission content limits in European waters (SECA) regions: $1 \%$ SFC in 2014 and $0.1 \%$ SFC in 2015.

Our $\mathrm{SO}_{2}$ emission estimate is low in part because we have purposely excluded local ship plumes. Also, $\Delta \mathrm{SO}_{2}$ could be a slight underestimate of ship emissions due to the assumption of zero ship influence in the southwestern wind sector. More accurate constraints of sulfur emissions from the English Channel from point measurements such as at PPAO probably require modeling of air trajectory/dispersion, detailed information about ship traffic, and knowledge of the $\mathrm{SO}_{2}$ source area (i.e., the concentration footprint; Wilson and Swaters, 1991; Schmid, 1994). A more complete description of the sulfur budget in this environment would also require sulfate concentration measurements in aerosols as well as in precipitation droplets.

\section{Conclusions}

In this paper, we analyzed 1.5 years of continuous atmospheric $\mathrm{SO}_{2}$ measurements on the coast of the English Channel. $\mathrm{SO}_{2}$ mixing ratio in southwesterly winds was generally low and showed a diel cycle that is largely consistent with DMS oxidation. In contrast, $\mathrm{SO}_{2}$ mixing ratio in southeasterly winds was elevated and more variable due to additional contribution from ships. This ship contribution was reduced by approximately 3-fold from 2014 to 2015 in response to the IMO regulation on sulfur emissions in European coastal waters. Apparent fuel sulfur content calculated from coincidental $\mathrm{SO}_{2}$ and $\mathrm{CO}_{2}$ peaks from local ship plumes suggest a high level of compliance (> $95 \%$ ) in both years. About $70 \%$ of ships were already emitting $\mathrm{SO}_{2}$ at levels below the 2015 cap in 2014. As ship sulfur emissions reduce, DMS becomes relatively more important to the atmospheric $\mathrm{SO}_{2}$ burden, accounting for about half of the atmospheric $\mathrm{SO}_{2}$ over the English Channel in 2015. Our data show that the residence time of $\mathrm{SO}_{2}$ in the marine atmosphere is approximately $0.5 \mathrm{~d}$, with dry deposition explaining about a quarter of the total $\mathrm{SO}_{2}$ sink. 


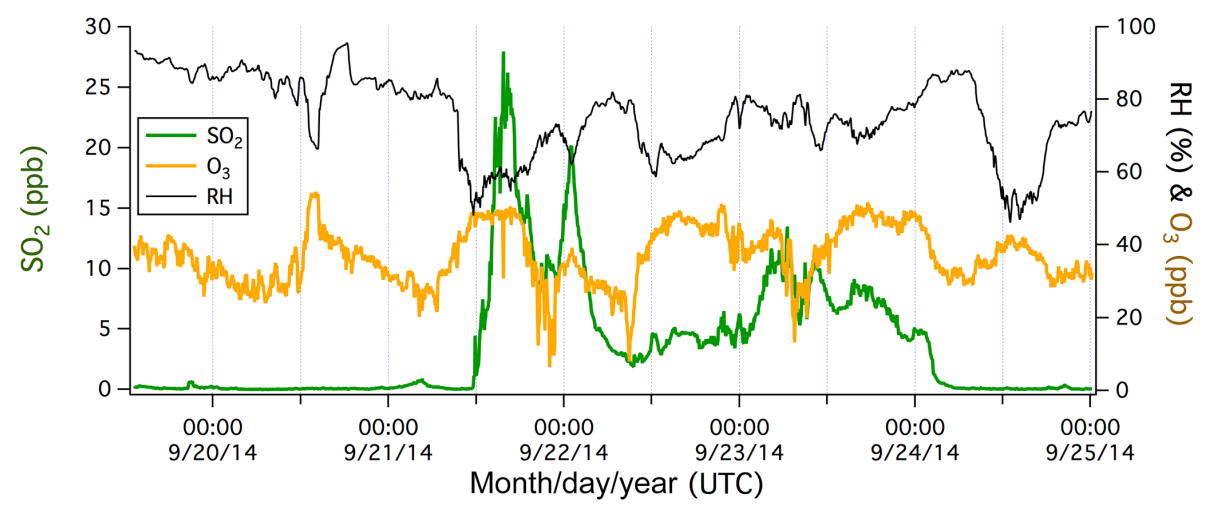

Figure A1. Very high $\mathrm{SO}_{2}$ mixing ratios were observed in Icelandic volcano plumes. Elevated $\mathrm{SO}_{2}$ sometimes coincided with increased $\mathrm{O}_{3}$ and reduced relative humidity $(\mathrm{RH})$, consistent with entrainment from the free troposphere.

\section{Appendix A: $\mathrm{SO}_{2}$ from volcanic eruption}

The Icelandic volcano Bárdarbunga was active for the spring and summer months of 2014. Under favorable meteorological conditions, $\mathrm{SO}_{2}$ emitted from the volcano was transported in the upper atmosphere from Iceland to the UK, where it was entrained into the atmospheric boundary layer. $\mathrm{SO}_{2}$ from volcanic eruption, with surface mixing ratios up to $30 \mathrm{ppb}$, was clearly detected at PPAO between 21 and 24 September 2014 (Fig. A1). These $\mathrm{SO}_{2}$ plumes were observed all over the UK (http://uk-air.defra.gov.uk) and were also apparent from space (e.g., $\mathrm{O}_{3}$ monitoring instrument, http://sacs.aeronomie. be/nrt/). Winds were generally from the northwest during these days of relatively high atmospheric pressure. Elevated $\mathrm{O}_{3}$ mixing ratios and reduced humidity generally coincided with the high $\mathrm{SO}_{2}$ mixing ratios in these plumes, qualitatively consistent with entrainment from the troposphere. These volcanic plumes of $\mathrm{SO}_{2}$ were outside of our southeastern and southwestern marine wind sectors. 
Acknowledgements. Trinity House (http://www.trinityhouse.co. uk/) owns the Penlee site and has kindly agreed to lease the building to PML so that the instruments can be protected from the elements. We are able to access the site thanks to the cooperation of Mount Edgcumbe Estate (http://www.mountedgcumbe.gov.uk/). Thanks to S. Atkinson and M. Sillett (Plymouth University) for routine maintenance of site, S. Ussher (Plymouth University), P. Agnew, N. Savage, and L. Neal (UK Met Office) for valuable scientific discussions, R. Pascal and M. Yelland (National Oceanography Centre, Southampton) for letting us deploy the Picarro instrument, and B. Carlton (Plymouth Marine Laboratory) for setting up data communication. We also thank the reviewers for their constructive comments and suggestions. T. Bell and M. Yang dedicate this publication to the late Roland von Glasow, who was a source of great inspiration and support to us both.

Edited by: E. Harris

\section{References}

Agrawal, H., Malloy, Q. G. J., Welch, W. A., Wayne Miller, J., and Cocker III, D. R.: In-use Gaseous and Particulate Matter Emissions from a Modern Ocean Going Container Vessel, Atmos. Environ., 42, 5504-5510, doi:10.1016/j.atmosenv.2008.02.053, 2008.

Archer, S. D., Cummings, D. G., Llewellyn, C. A., and Fishwick, J. R.: Phytoplankton taxa, irradiance and nutrient availability determine the seasonal cycle of DMSP in temperate shelf seas, Mar. Ecol. Prog. Ser., 394, 111-124, doi:10.3354/meps08284, 2009.

Aulinger, A., Matthias, V., Zeretzke, M., Bieser, J., Quante, M., and Backes, A.: The impact of shipping emissions on air pollution in the greater North Sea region - Part 1: Current emissions and concentrations, Atmos. Chem. Phys., 16, 739-758, doi:10.5194/acp16-739-2016, 2016.

Bandy, A. R., Thornton, D. C., Blomquist, B. W., Chen, S., Wade, T. P., Ianni, J. C., Mitchell, G. M., and Nadler, W.: Chemistry of dimethyl sulfide in the equatorial Pacific atmosphere, Geophys. Res. Lett., 23, 741-744, 1996.

Beecken, J., Mellqvist, J., Salo, K., Ekholm, J., Jalkanen, J.-P., Johansson, L., Litvinenko, V., Volodin, K., and Frank-Kamenetsky, D. A.: Emission factors of $\mathrm{SO}_{2}, \mathrm{NO}_{x}$ and particles from ships in Neva Bay from ground-based and helicopter-borne measurements and AIS-based modeling, Atmos. Chem. Phys., 15, 52295241, doi:10.5194/acp-15-5229-2015, 2015.

Campanella, L., Cipriani, P., Martini, T. M., Sammartino, M. P., and Tomassetti, M.: New enzyme sensor for sulfite analysis in sea and river water samples, Anal. Chim. Acta, 305, 32-41, 1995.

Capaldo, K., Corbett, J. J., Kasibhatla, P., Fischbeck, P. S., and Pandis, S. N.: Effects of ship emissions on sulphur cycling and radiative climate forcing over the ocean, Nature, 400, 743-746, 1999.

Charlson, R. J. and Rodhe, H.: Factors controlling the acidity of rainwater, Nature, 295, 683-685, 1982.

Charlson, R. J., Lovelock, J. E., Andreae, M. O., and Warren S. G.: Oceanic phytoplankton, atmospheric sulfur, cloud albedo and climate, Nature, 326, 655-661, 1987.

Clarke, A. D., Davis, D., Kapustin, V. N., Eisele, F., Chen, G., Paluch, I., Lenschow, D., Bandy, A. R., Thornton, D., Moore, K., Mauldin, L., Tanner, D., Litchy, M., Carroll, M. A., Collins,
J., and Albercook, G.: Particle nucleation in the tropical boundary layer and its coupling to marine sulfur sources, Science, 282, 89-92, 1998.

Chen, G., Davis, D. D., Kasibhatla, P., Bandy, A. R., Thornton D. C., Huebert, B. J., Clarke, A. D., and Blomquist, B. W.: A study of DMS oxidation in the tropics: comparison of Christmas Island field observations of DMS, $\mathrm{SO}_{2}$, and DMSO with model simulations, J. Atmos. Chem., 37, 137-160, 2000.

Collins, W. J., Sanderson, M. G., and Johnson, C. E.: Impact of increasing ship emissions on air quality and deposition over Europe by 2030, Meteorologische Z., doi:10.1127/09412948/2008/0296, published online, 2008.

Corbett, J. J., Winebrake, J. J., Green, E. H., Kasibhatla, P., Eyring, V., and Lauer, A.: Mortality from Ship Emissions: A Global Assessment, Environ. Sci. Technol., 41, doi:10.1021/es071686z, 8512-8518, 2007

Cuong, N, B. C., Bonsang, B., Lambert, G., and Pasquier, J. L. Residence time of sulfur dioxide in the marine atmosphere, Pure Appl. Geophys., 123, 489-500, 1975.

Dalsøren, S. B., Eide, M. S., Endresen, Ø., Mjelde, A., Gravir, G., and Isaksen, I. S. A.: Update on emissions and environmental impacts from the international fleet of ships: the contribution from major ship types and ports, Atmos. Chem. Phys., 9, 2171-2194, doi:10.5194/acp-9-2171-2009, 2009.

Davis, D., Chen, G., Bandy, A., Thornton D., Eisele, F., Mauldin, L., Tanner, D., Lenschow, D., Fuelberg, H., Huebert B., Heath, J., Clarke, A., and Blake, D.: Dimethylsulfide oxidation in the equatorial Pacific: comparison of model simulations with field observations for DMS, $\mathrm{SO}_{2}, \mathrm{H}_{2} \mathrm{SO}_{4}(\mathrm{~g}), \mathrm{MSA}(\mathrm{g}), \mathrm{MS}$, and NSS, J. Geophys. Res., 104, 5765-5784, 1999.

Eigen, M., Kruse, W., Maass, G., and De Maeyer, L.: Rate constants of protolytic reactions in aqueous solution, in: Progress in Reaction Kinetics, Vol. 2, edited by: Porter, G., 285-318, Pergamon, Oxford, 1964.

Endresen, Ø., Sørgård, E., Sundet, J. K., Dalsøren, S. B., Isaksen, I. S. A., Berglen, T. F., and Gravir, G.: Emission from international sea transportation and environmental impact, J. Geophys. Res., 108, 4560, doi:10.1029/2002JD002898, 2003.

Eyring, V., Koehler, H. W., van Aardenne, J., and Lauer, A.: Emissions from international shipping: 1 . The last 50 years, J. Geophys. Res., 110, D17305, doi:10.1029/2004JD005619, 2005 a.

Eyring, V., Köhler, H. W., Lauer, A., and Lemper, B.: Emissions from international shipping: 2. Impact of future technologies on scenarios until 2050, J. Geophys. Res., 110, D17306, doi:10.1029/2004JD005620, 2005b.

Fairall, C. W., Yang, M., Bariteau, L., Edson, J. B., Helmig, D., McGillis, W., Pezoa, S., Hare, J. E., Huebert, B., and Blomquist, B.: Implementation of the Coupled Ocean-Atmosphere Response Experiment flux algorithm with $\mathrm{CO}_{2}$, dimethyl sulfide, and $\mathrm{O}_{3}$, $\mathrm{J}$. Geophys. Res., 116, C00F09, doi:10.1029/2010JC006884, 2011.

Hayes, M., Taylor, G., Aster, Y. M., and Scranton, M. J.: Vertical distributions of thiosulfate and sulfite in the Cariaco Basin, Limnol. Oceanogr. 01/2006, 51, 280-287, doi:10.4319/lo.2006.51.1.0280, 2006.

Hegg, D. A.: The importance of liquid-phase oxidation of $\mathrm{SO}_{2}$ in the troposphere, J. Geophys. Res., 20, 3773-3779, 1985.

Jalkanen, J.-P., Johansson, L., and Kukkonen, J.: A comprehensive inventory of ship traffic exhaust emissions in the European sea 
areas in 2011, Atmos. Chem. Phys., 16, 71-84, doi:10.5194/acp16-71-2016, 2016.

Johnson, M. T.: A numerical scheme to calculate temperature and salinity dependent air-water transfer velocities for any gas, Ocean Sci., 6, 913-932, doi:10.5194/os-6-913-2010, 2010.

Kattner, L., Mathieu-Üffing, B., Burrows, J. P., Richter, A., Schmolke, S., Seyler, A., and Wittrock, F.: Monitoring compliance with sulfur content regulations of shipping fuel by in situ measurements of ship emissions, Atmos. Chem. Phys., 15, 10087-10092, doi:10.5194/acp-15-10087-2015, 2015.

Liss, P. S. and Slater, P. G.: Flux of Gases across the air-sea interface, Nature, 247, 181-184, 1974.

Lynch, J. A., Bowersox, V. C., and Grimm, J. W.: Changes in sulfate deposition in eastern USA following implementation of Phase I of Title IV of the Clean Air Act Amendments of 1990, Atmos. Environ., 34, 1665-1680, 2000.

Malm, W. C., Schichtel, B. A., Ames, R. B., and Gebhart, K. A.: A 10-year spatial and temporal trend of sulfate across the United States, J. Geophys. Res., 107, 4627, doi:10.1029/2002JD002107, 2002.

Matthias, V., Bewersdorff, I., Aulinger, A., and Quante, M.: The contribution of ship emissions to air pollution in the North Sea regions, Environ. Pollut., 158, 2241-2250, 2010.

Schmid, H. P.: Source areas for scalars and scalar fluxes, Bound. Lay. Meteorol., 67, 293-318, 1994.

Schwartz, S. E.: Factors governing dry deposition of gases to surface water, in: Precipitation Scavenging and Atmosphere-Surface Exchange, edited by: Schwartz, S. E. and Slinn, W. G. N., Volume ii, Hemisphere Publishing Corp, Washington, 1992.

Shon, Z. H., Davis, D., Chen, G., Grodzinsky, G., Bandy, A., Thornton, D., Sandholm, S., Bradshaw, J., Stickel, R., Chameides, W., Kok, G., Russell, L., Mauldin, L., Tanner, D., and Eisele, F.: Evaluation of the DMS flux and its conversion to $\mathrm{SO}_{2}$ over the southern ocean, Atmos. Environ., 35, 159-172, 2001.

Simpson, R. M. C., Howell, S. G., Blomquist, B. W., Clarke, A. D., and Huebert, B. J.: Dimethyl sulfide: Less important than long-range transport as a source of sulfate to the remote tropical Pacific marine boundary layer, J. Geophys. Res.-Atmos., 119, 9142-9167, doi:10.1002/2014JD021643, 2014.

Vestreng, V., Myhre, G., Fagerli, H., Reis, S., and Tarrasón, L.: Twenty-five years of continuous sulphur dioxide emission reduction in Europe, Atmos. Chem. Phys., 7, 3663-3681, doi:10.5194/acp-7-3663-2007, 2007.

von Glasow, R., Lawrence, M. G., Sander, R., and Crutzen, P. J.: Modeling the chemical effects of ship exhaust in the cloudfree marine boundary layer, Atmos. Chem. Phys., 3, 233-250, doi:10.5194/acp-3-233-2003, 2003.

Whall, C., Scarborough, T., Stavrakaki, A., Green, C., Squire, J., and Noden, R.: UK Ship Emissions Inventory, Entec UK Ltd, London, UK, available at: http://uk-air.defra.gov.uk/assets/documents/reports/cat15/ 1012131459_21897_Final_Report_291110.pdf (last access: January 2010), 2010.
Wilson, J. D. and Swaters, G. E.: The Source Area Influencing a Measurement in the Planetary Boundary Layer: The "Footprint" and the "Distribution of Contact Distance", Bound.Lay. Meteorol., 55, 25-46, 1991.

Winebrake, J. J., Corbett, J. J., Green, E. H., Lauer, A., and Eyring, V.: Mitigating the health impacts of pollution from oceangoing shipping: An assessment of low-sulfur fuel mandates, Environ. Sci. Technol., 43, 4776-4782, 2009.

Yang, M., Blomquist, B. W., and Huebert, B. J.: Constraining the concentration of the hydroxyl radical in a stratocumulus-topped marine boundary layer from sea-to-air eddy covariance flux measurements of dimethylsulfide, Atmos. Chem. Phys., 9, 92259236, doi:10.5194/acp-9-9225-2009, 2009.

Yang, M., Blomquist, B. W., Fairall, C. W., Archer, S. D., and Huebert, B. J.: Air-sea exchange of dimethylsulfide in the Southern Ocean: Measurements from SO GasEx compared to temperate and tropical regions, J. Geophys. Res., 116, C00F05, doi:10.1029/2010JC006526, 2011a.

Yang, M., Huebert, B. J., Blomquist, B. W., Howell, S. G., Shank, L. M., McNaughton, C. S., Clarke, A. D., Hawkins, L. N., Russell, L. M., Covert, D. S., Coffman, D. J., Bates, T. S., Quinn, P. K., Zagorac, N., Bandy, A. R., de Szoeke, S. P., Zuidema, P. D., Tucker, S. C., Brewer, W. A., Benedict, K. B., and Collett, J. L.: Atmospheric sulfur cycling in the southeastern Pacific longitudinal distribution, vertical profile, and diel variability observed during VOCALS-REx, Atmos. Chem. Phys., 11, 50795097, doi:10.5194/acp-11-5079-2011, 2011b.

Yang, M., Beale, R., Smyth, T., and Blomquist, B.: Measurements of OVOC fluxes by eddy covariance using a proton-transferreaction mass spectrometer - method development at a coastal site, Atmos. Chem. Phys., 13, 6165-6184, doi:10.5194/acp-136165-2013, 2013.

Yang, M., Bell, T. G., Hopkins, F. E., Kitidis, V., Cazenave, P. W., Nightingale, P. D., Yelland, M. J., Pascal, R. W., Prytherch, J., Brooks, I. M., and Smyth, T. J.: Air-Sea Fluxes of $\mathrm{CO}_{2}$ and $\mathrm{CH}_{4}$ from the Penlee Point Atmospheric Observatory on the South West Coast of the UK, Atmos. Chem. Phys. Discuss., doi:10.5194/acp-2015-717, in review, 2016.

Yvon, S. A., Plane, J. M. C., Nien, C.-F., Cooper, D. J., and Saltzman, E. S.: The interaction between the nitrogen and sulfur cycles in the polluted marine boundary layer, J. Geophys. Res., 101, 1379-1386, 1996.

Zhao, J. and Zhang, R. Y.: Proton transfer reaction rate constants between hydronium ion $(\mathrm{H} 3 \mathrm{O}+)$ and volatile organic compounds, Atmos. Environ., 38, 2177-2185, 2004. 